\title{
Personalizace na komunální úrovni: existuje a lze ji v českém prostředí zkoumat?
}

\author{
ANDREA SMOLKOVÁ, Stanislav BALÍK ${ }^{1}$
}

\begin{abstract}
Against the background of current research and literature, the article discusses local levelpersonalization in the Czech Republic as well as the ways it can be studied. Emphasising topics such as personalization of the electoral behaviour, electoral system, and political elites' strategy, the authors present a novel research design aimed at identifying and better understanding the phenomenon of personalization on the local level. The research design develops some original identifiers such as popularity of the candidate, while also employing traditional criteria such as preferential voting or incumbency effect.
\end{abstract}

Keywords: Personalization; Czech Republic; Local Elections; Preferential Voting; Electoral Behaviour; Electoral System; Research Design

\section{1. Úvodem}

Společenský vývoj přelomu 20. a 21. století dává prostor $\mathrm{k}$ rozvoji relativně nových fenoménů, které se promítají i do politiky. Jedním z nich je personalizace - jev, který je charakteristický pro mnoho liberálních demokracií současné doby (McAllister 2005) a stává se tak aktuálním trendem. Výzkumu personalizace se u nás i v zahraničí věnuje mnoho autorů. Pozornost je ale směřována především k národní úrovni politiky, což je dáno i částečně tím, že pưvodně byl tento jev silně spojován s prezidentskými typy demokracií. Postupně ale zjišt'ujeme, že v různých zemích dochází $\mathrm{k}$ různé míre personalizace politiky (Karvonen 2010). Personalizace tedy je př́tomna v různých typech politických i stranických systému, bez ohledu na systém volební. Platí to ale i pro nižší úrovně politiky? Mủže být

\footnotetext{
${ }^{1}$ Katedra politologie, Fakulta sociálních studií, Masarykova univerzita, Joštova 10, 60200 Brno / Department of Political Science, Faculty of Social Studies, Masaryk University, Czech Republic. Email: andrea.smolkova@mail.muni.cz,balik@fss.muni.cz
} 
personalizace $\mathrm{v}$ určité mî́re prítomna i uvnitř českého komunálního systému? A hlavně - jakými metodami a nástroji to můžeme zjistit?

Poslední zmiňovaná otázka je tou základní, na kterou v předkládaném textu budeme hledat odpověd’. Komunální prostř̌edí je zajímavým případem, kterému je obecně $\mathrm{v}$ rámci české politologie věnováno prostoru poměrně dost - existují výzkumy týkající se problematičnosti volebního systému, využívání preferenčního hlasování i volebního chování (srov. Lebeda 2009, 2011; Balík, Gongala a Gregor 2015). Nicméně samotný fenomén personalizace $\mathrm{v}$ nich nehraje zásadní úlohu a prítomnost personalizace na komunální úrovni tak není prozatím v české politologii zásadním tématem. Mưže to být dáno několika faktory. Jedním z nich jsou rozdíly mezi politickými systémy založeny na jejich velikosti - atraktivnější může být zkoumat politické systémy na úrovni národní než lokální, což může mít jistou souvislost s teorií voleb druhého řádu (Reif a Schmitt 1980). Dalším důvodem může být i jistá obtížnost zkoumání tohoto fenoménu na komunální úrovni, daná do jisté míry i absencí konceptu a výzkumného designu pro komunální úroveň. O tom, že jisté odlišnosti mezi národní a lokální úrovní, co se týče fenoménu personalizace, existují, nicméně nemůže být pochyb. Odlišnosti jsou dány zejména rozdílnou velikostí volební arény a z ní vyplývajících charakteristik těchto různých volebních systémů - je např́iklad přirozené, že čím menší je velikost volebního obvodu, tím větší může být známost kandidáta ucházejícího se o funkci, a tím bližší může být daná volební agenda konkrétnímu voliči (srov. Dahl a Tufte 1973).

Bez ohledu na zvyšující se zájem o fenomén personalizace na národní úrovni zůstává stále potřeba jejího pochopení na úrovni komunální. Následující text má jednak ambici předložit ucelený souhrn toho, jak lze personalizaci na komunální úrovni konceptualizovat a jakými metodami a nástroji ji lze zkoumat. Uvádí tedy do tématu personalizace komunální politiky, když nabízí konceptualizaci tohoto fenoménu v podání předních výzkumníků, a zkoumá související procesy a faktory, které personalizaci umožňují nebo posilňují, stejně jako změny, které s sebou přináší. Zaměřuje se přitom nejenom na výzkum personalizace volebního chování jako takového, ale i na vztah personalizace $\mathrm{k}$ institucionálnímu nastavení volebního systému a ke strategii politických elit (srov. Kouba 2016). Na tomto pozadí je ale hlavním autorským cílem nabídnout vlastní formu a způsob, jakým fenomén personalizace na komunální úrovni měrit a tím pádem i identifikovat jeho (ne)př́tomnost v systému. Jinými slovy, předkládáme zde originální design výzkumu, který by $\mathrm{k}$ těmto účelům měl dokázat posloužit. Cílem tohoto textu tudíž není prezentace výsledků empirického výzkumu, nýbrž spíše ukázání cesty, která by k takovému výzkumu mohla vést. Tato snaha tak může pomoci $\mathrm{k}$ vyplnění dalšího bílého místa $\mathrm{v}$ české politické vědě, která se personalizaci na komunální úrovni nevěnuje dosud žádnou př́padovou studií ani metodologickým článkem, který by vhodné metody a postupy takového výzkumu navrhoval. Vlastní empirický výzkum provedený podle tohoto originálního designu pak může 
přinést data užitečná hned pro několik politologických disciplín - využití mohou najít v politickém marketingu, volebním chování nebo jako podklad pro potenciální reformu komunálního volebního systému.

Výše uvedenému odpovídá i struktura textu. Nejprve představujeme koncept personalizace a její trojdimenzionální pojetí, následně seznamujeme čtenáře s možnými definicemi fenoménu personalizace. $\mathrm{V}$ poslední části pak prostřednictvím vlastního návrhu výzkumného designu nastiňujeme možnosti, jak tento fenomén zkoumat $\mathrm{v}$ komunální politice.

\section{Koncept personalizace (lokální) politiky aneb trojdimenzionální pojetí}

Ačkoli je personalizace politiky relativně moderním a významným fenoménem (Benett 2012; Blondel 2011; Kriesi 1998 a dalši), kořeny konceptu jsou hluboké (srov. Karvonen 2009; Garzia 2011). Někteří autoři jej dokonce označují za jev starý tak, jako je stará sama politika (Poguntke a Webb 2005: 76). Na tom, co ale personalizace přesně znamená, zatím neexistuje absolutní shoda, jak už tomu v sociálních vědách bývá. Definic je několik, ale žádná všeobecně prijiímaná.

O personalizaci politiky - tedy zájmu o kandidáty, o konkrétní osobnosti, v kontrastu s politickými subjekty jako celky (Voženílková 2014: 2) - se začalo poprvé hovořit už $\mathrm{v}$ průběhu 60 . let minulého století v souvislosti s takzvaným zosobnèním politiky - a to jak ve směru od kandidátů, tak od voličů. Definování personalizace $\mathrm{v}$ obou směrech je velmi důležité. Někteří autoři totiž personalizaci definují pouze jako jednosměrný proces z pohledu politických stran (srov. Šo̊stková 2007; Pecháček 2013). Fenomén personalizace je ale svázán s několika podstatnými procesy druhé poloviny 20. století, které zásadním způsobem ovlivnily nejen západní demokracie a určitým způsobem osvětlují důvody, proč není personalizace ohraničena pouze vazbou politická strana - kandidát, ale podstatnou roli hraje i elektorát.

Těmito procesy jsou individualizace, rozpad tradičních konfliktních linií a modernizace (Voženílková 2014: 4-5). Individualizace narušila tradiční vnímání politiky, která byla založena a organizována na principu tradičního kolektivismu, kde individuální zájem byl tradičně podřízen zájmům společným, resp. společenským (Biler 2008: 29). Rozpad tradičních konfliktních linií - tzv. cleavages (Lipset a Rokkan 1967) - zase vedl k nižší míře identifikace voličů s tradičními politickými stranami a oslabení jejich voličské loajality vůči těmto politickým subjektům. Transformací a oslabováním těchto základních politických struktur se jiné než kolektivní loajality a identity staly určujícími pro politické chování a preference voličů (Karvonen 2009: 3). V důsledku oslabení tradičních vazeb se 
voliči posunuli více do středu politického spektra, ${ }^{2}$ načež stejným posunem odpověděly i politické subjekty. Zároveň rozšíríly svůj program takovým způsobem, aby zaujaly co nejvíce voličů (tzv. catch-all strany). Tím se však staly málo výraznými, což vedlo $\mathrm{k}$ tomu, že jejich programy a ideologické zakotvení jsou převyšovány osobními charakteristikami jak kandidátů, tak i voličů (Caprara a Zimbardo 2004: 581). Třetím prvkem, se kterým jde personalizace ruku v ruce, je rozvoj moderních médií. V literatuře je tento proces často spojován zejména s masovým rozšířením televize (srov. Gunther a Mughan 2000: 402; Karvonen 2009: 4), aktuálně je $\mathrm{k}$ tomu více než vhodné přidat i tzv. nová média, tedy sociální sítě, které $\mathrm{v}$ dnešní době zažívají obrovský boom a jejichž začlenění do politické komunikace je takříkajíc nutností. ${ }^{3}$ Dnešní političtí vůdcové, at' už jsou u moci nebo o ni usilují, nemají př́liš na vybranou - musí pečlivě dbát na to, jak sami sebe prezentují před „vzdálenými“ lidmi, jejichž věrnost musí neustále přiživovat a jejichž aktivní podpora je pro ně čas od času životně důležitá (Thompson 2004: 111-113).

Ke třem procesům zmiňovaným odbornou literaturou na národní úrovni je důležité, vzhledem $\mathrm{k}$ tématu předkládaného textu, zmínit i koncept takzvané nepolitické politiky, který bývá často spojován nejen s politikou komunální v České republice. Obecně bývá komunální politika, a od toho se odvijející i kampaň a komunikace kandidátů, respektive později zvolených zástupců, považována za nepolitickou či spíše technicistní (srov. Balík 2009: 217). Pravdou ale je, že určité konflikty, na kterých se profilují spíše samotní kandidáti (nebo již zvolení zástupci), existují. Dají se charakterizovat pojmem polémos, který zpopularizoval významný český politický filozof Vladimír Čermák. Nejde tím pádem o spory nebo konfliktní linie ideologického, ale spíše ideového charakteru, jejichž přítomnost v komunální politice potvrdil i Balík (2016: 75). Komunální politiku můžeme považovat za nepolitickou právě z toho důvodu, že často nelze jednoznačně určit ideologické směřování jednotlivých kandidujících subjektů, bez ohledu na to, jestli jejich kandidaturu zaštit'uje etablovaná politická strana či hnutí, anebo se jedná o kandidátku složenou z nestraníků. A naopak můžeme pozorovat podobný pohled na řešení problémů v komunální politice u kandidátů napřric jednotlivými kandidátními listinami. Tito kandidáti spolu sdílí podobný pohled, který ale často nemá zakotvení v žádné z etablovaných ideologií. ${ }^{4}$

Z toho právě vyplývá jakési individuální chování politických elit, které se může projevovat různými zpơsoby. Jedná se o charakteristiku, která zapadá do moderních procesů majících vliv na individualizaci politického prostředí

2 Tento fenomén zachycuje teorie mediánového voliče - strany, a tím pádem i kandidáti, se přirozeně snaží oslovit co nejvíce voličů, a proto se jejich ideje a veřejné vystupování mohou v určitém smyslu stát méně radikální. $V$ důsledku toho se mohou snažit přibližit středu politického spektra a zvyšovat tak šance na své zvolení (srov. Hindmoore 2006).

${ }^{3}$ Politici dnes ke své komunikaci běžně používají Facebook, Twitter, Instagram nebo YouTube.

${ }^{4}$ Př́kladem budiž nejrůznější ,divoké“ koalice složené např́iklad ze zástupců KSČM a pravicových stran, které na národní úrovni stojí na opačných stranách politického spektra. 
a pravděpodobně i na personalizaci politiky na komunální úrovni v ČR. Pokud je totiž politika na komunální úrovni takzvaně nepolitická, může to znamenat, že volič hledá takového kandidáta či volební uskupení, které se nevymezuje ideologicky ve stranickém či politickém slova smyslu, ale působí „,nezávisle“, „nepoliticky“. A takovému obrazu se může snažit přiblížit i onen kandidát, což se může promítnout i do politické komunikace daného uskupení. V kontextu české komunální politiky mohou voliči také hojně využívat panašování, tedy (domněle) volit osobnosti např́č kandidátními listinami (srov. Lebeda 2009; viz také níže 2b.). Na to zároveň mohou spoléhat i samotná volební uskupení, která budou vybírat a na své kandidátní listiny zařazovat nezávislé kandidáty bez politické př́slušnosti, osobnosti reprezentující jisté voličské základny a společenské kategorie, které uskupení mohou přinést vytoužené hlasy, a podobně. Charakter odosobnění politiky tak může být na komunální úrovni zřejmější právě díky procesu individualizace, který byl popsán výše.

Výše uvedené procesy tedy měly zásadní vliv na prohloubení politické transformace systému (srov. Baumann 2011) a tím pádem i na rostoucí míru personalizace $\mathrm{v}$ politice. Jedná se o trendy, které se různými způsoby promítají i do definování tohoto pojmu. Kořeny a postupný rozvoj procesu personalizace v podobném duchu vystihuje i dvojice autorů G. V. Caprara a P. G. Zimbardo (2004: 581). Vliv médií v rámci personalizace politiky sleduje napr. Lisbeth van Zoonen. Ta uvádí jako zdroje personalizace tř́ důvody: 1) v prostředí přehlceném texty a obrazy umožňuje personalizace efektivně zhustit informace, jež př́jemci potřebují pro své politické rozhodování; 2) individuality lépe zapadají do dominantního kulturního rámce zábavy a jejích žánrů; 3) politik proto musí neustále přepínat mezi různými požadavky politiky a zábavou tak, aby si udržel svoje postavení (van Zoonen 2005: 69)

Hanspeter Kriesi sleduje personalizaci politiky prostřednictvím dvou procesů. Jak uvádí Voženílková (2014: 10), jeho konceptualizace by pak mohla být chápána jako průseč́k Caprary a Zimbarda na jedné straně a van Zoonen na straně druhé. Zaprvé, Kriesi personalizaci připisuje procesu stranického systému, kdy občané už nejsou spoutáni s určitou stranou, ale zvyšuje se zaměření na specifické otázky, individuální politické lídry a další kandidáty při volebním rozhodování (dealignment). Zadruhé je tento trend chápán jako posilování médií, které rozvinuly svou vlastní mediální logiku k pokrytí politiky obecně a zejména pak politické kampaně (Kriesi 2010: 2).

\section{a. Definice}

Jak tedy personalizaci politiky definovat? Přestože je fenomén personalizace akceptován a daný termín nejrůzněji používán veřejností i v odborných kruzích, 
jednotná definice zatím neexistuje, což může znesnadňovat další práci. ${ }^{5}$ Zásadní pro výběr vhodné definice je fakt, že se jedná o moderní jev, který obsahuje prvek změny (Voženílková 2014: 11). Např. Lauri Karvonen (2009: 4 jej definuje jako proces $\mathrm{v}$ čase: $\mathrm{v}$ čase $t$ byla politika méně personalizovaná než $\mathrm{v}$ čase $t+1$. Personalizace politiky je spojena s nástupem nových procesů a trendů, př́padně technologií. Jedná se o projev přechodu od „tradiční k moderní politice“. Balmas et al. (2012: 10) tvrdí, že politická personalizace znamená změnu v distribuci moci dvěma možnými směry: centralizací ( $\operatorname{moc}$ se přesunuje nahoru ke stranickým lídrům, premiérům) a decentralizací ( $\operatorname{moc}$ se přesunuje dolů $\mathrm{k}$ individuálním politikům). Centralizovaná podoba odkazuje $\mathrm{k}$ tomu, že voliči volí více na základě ztotožnění se s lídrem a méně na základě obliby či sounáležitosti se stranou (Balmas et al. 2014: 40). Do této části mohou být řazeny i výzkumy věnující se postavení, popularitě lídra u voličů. Související výzkumy se snaží objasnit jednak poměr hlasů pro strany udělený právě na základě identifikace s lídrem (napřs. studie německých voleb mezi lety 1961 až 1998; viz Schmitt a Ohr 2000 či Kaase 1994). Vznikají práce věnující se spíše samotné postavě lídra, tedy jeho osobnostním a profesním charakteristikám, které vedou ke zvýšené pravděpodobnosti personalizované volby (Garzia 2011; Kinder 1986; Miller a Miller 1976). Naopak decentralizovaná forma této dimenze vychází z předpokladu, že voliči se rozhodují dle širší identifikace $\mathrm{s}$ větším počtem individuálních kandidátů (ne politickými lídry), opět na úkor sympatie ke straně či identifikace s ní (Balmas et al. 2014: 40). Přestože behaviorální dimenze personalizace zůstává vědecky spíše neprobádanou oblastí, jedná se o jedno z klíčových polí, kde mohou být hledány alespoň některé príčiny trendu změny voličského chování $\mathrm{v}$ západních demokraciích (jehož dokladem může být i kontext posledních voleb).

Obecně řečeno, personalizace souvisí s rušením tradičních cleavages a nástupem nových, nebo také s rozvolněním vazby politická strana-volič a její nahrazením vztahem kandidát-volič (Voženílková 2014: 11). Tento bod je pro další úvahy poměrně zásadní, nebot' na první pohled by se mohlo zdát, že personalizaci ovlivňují aktérí pouze dva, a sice kandidát a volič (ibid.). Je nutné si uvědomit, že aktéry personalizace jsou subjekty tři - kandidát, volič a nominující subjekt, tedy politická strana nebo hnutí. Tento trojstranný vztah je velice významný pro pochopení celého procesu personalizace politiky jako moderního fenoménu, který dnes postihuje všechny liberální demokracie (McAllister 2005: 1). Nominující subjekt ustupuje do pozadí a program - ideologie, politiky, cíle - je prezentová skrze jednotlivce, především lídry. Političtí lídři jsou nyní důležití nejen proto, aby přiměli voliče volit, ale i pro mobilizaci jako takovou (což byla tradiční úloha stran). Důraz na tři aktéry kladou např. Carsten Reinemann a Jürgen Wilke, kteří

\footnotetext{
${ }^{5}$ Ani česká literatura nedisponuje sjednocenou definicí pojmu personalizace politiky a místy se tak uchyluje ke jeho zkratkovitému chápání. Kvůli tomu se často objevuje nesprávné užívání pojmu v kontaminaci termíny jako je individualizace, prezidencializace nebo celebritizace (srov. Voženílková 2014: 13).
} 
personalizaci definují jako proces rostoucího zájmu médií o jednotlivé politiky jakožto individuality, na úkor politických skupin, stran a ideologií, V užším slova smyslu pak pod personalizací rozumí soustředěnější pozornost médií osobnostním charakteristikám politiků (Reinemann a Wilke 2001: 293). Kriesi zase tvrdí, že personalizace odpovídá dvěma přibuzným fenoménům: Silnějšímu zaměření se na kandidáta namísto strany, instituce nebo tématu, a změně v kritériích hodnocení vlastností politiků - od těch týkajících se jejich odborné způsobilosti a výkonu k funkcím k nepolitickým osobnostním rysům (Kriesi 2010: 2).

Caprara a Zimbardo (2004: 581) užívají tuto definici: „Moderní politika se stává personalizovanou s tím, jak individuální charakteristiky voličů a kandidátů získávají na větším významu v politickém diskursu. Důraz je kladen na individuální charakteristiky kandidátů i voličů, přičemž voliči hlasuji pro ty kandidáty, jejichž charakteristiky se co nejvíce blíží jejich vlastním“. Pro zjednodušení pak můžeme tvrdit, že personalizace znamená otevřenost volby, která voliči umožňuje respektovat individuální zvláštnosti sebe sama i kandidátů. Caprarova a Zimbardova definice je pro účely předkládaného textu zásadní, vezmeme-li v úvahu dosavadní poznatky o tom, jak moc je stávající komunální volební systém v ČR matoucí a jakým způsobem $\mathrm{k}$ němu prisstupuje běžný volič, který se detailně nezajímá o mechanismus přepočtu hlasů na mandáty (srov. Lebeda 2009). ${ }^{6}$ Tato definice v sobě také odráží tři typy personalizace, které rozlišují Rahat a Sheafera (2007: 66). Zaprvé institucionální, což je zvýšený důraz na kandidáty zpo̊sobený změnou vnitrostranických mechanismů uvnitř politických stran. Zadruhé mediální, neboli proměna prezentace politiky v médiích - jedná se o změnu nastavení politických strategií elit. A zatřetí behaviorální, která znamená změnu v chování politiků a percepci politiky publikem; jinými slovy tu personalizaci volebního chování, která je pro další text klíčová. A je zřejmé, že všechny tři zmíněné typy vycházejí z procesu individualizace, o kterém se zmiňujeme výše.

Hanspeter Kriesi (2010: 4-6) jde v typologii personalizace, ale v souladu s výše uvedeným, o úroveň dál a určuje tř́ faktory determinující stupeň fenoménu personalizace:

1. politická rozhodnutí jsou stále více individualizována - závisí na tom, co volič chce nebo nechce, na jeho osobních soudech. To ovlivňuje voličovo chování mnohem více než vzdělání, pohlaví, věk a další proměnné, které řídily rozhodování v minulosti;

2. mediální systém neboli typ médií a styl komunikace v kampani;

3. specifický kontext voleb - na personalizaci má vliv aktuální konfigurace stran, kandidátů a rovněž témat převládajících v předvolební kampani.

\footnotetext{
${ }^{6}$ Nutno ovšem podotknout, že v praxi zatím neexistuje komplexnější výzkum, který by pohled voličů na komunální volební systém v ČR analyzoval a dokázal určit míru nepochopení aktuálně platných volebních pravidel. Jinými slovy, není zatím empiricky podloženo, do jaké míry běžný volič v ČR o panašování uvažuje jako o přímém hlasu pro kandidáta.
} 
Z toho je patrné, že personalizace se může ve volební aréně různě stupňovat. Odborná literatura se $\mathrm{v}$ této souvislosti zaměřuje také na vzájemný vztah mezi jednotlivými úrovněmi personalizace, přičemž pohledy na něj jsou $\mathrm{v}$ zásadě dva. První rríká, že vztah reprezentuje jednosměrnou kauzální sekvenci ve smyslu začátku politických změn jako je takzvaná nová politika (srov. Dalton 2002; Inglehart 1997), po které přišel pokles členství v politických stranách. Tyto změny pak vedly $\mathrm{k}$ personalizaci institucionální a ta pak $\mathrm{k}$ personalizaci mediální, a toto vše nakonec vedlo k personalizaci volebního chování. Jak ale podotýká Kouba (2016: 10), takovýto jednosměrný kauzální vztah je př́liš zjednodušující a nedokáže zohlednit vzájemné působení jednotlivých aspektů personalizace. To podstatně lépe vystihuje následující schéma č. 1:

\section{Schéma č.1: Vztah mezi úrovněmi personalizace}

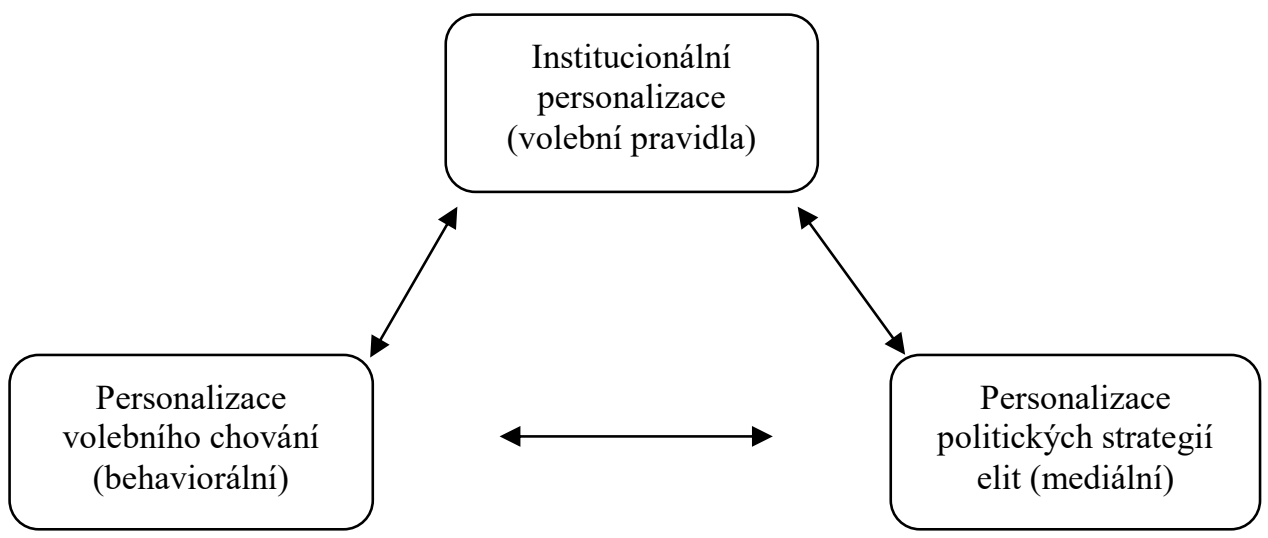

Zdroj: Kouba (2016: 9).

Z tohoto schématu je patrné, že personalizace volebního chování může být př́činou, ale i důsledkem personalizace institucionální nebo mediální. V praxi je tak velmi těžké posoudit, jestli např́klad volební reforma, která způsobí zavedení více personalistického typu volebního systému, je reakcí na společenskou poptávku, nebo sama o sobě podnítí voliče ke hledání osobností namísto stranických alternativ (Kouba 2016: 10). Toto se může týkat i některých nejasností kolem českého komunálního volebního systému.

\section{b. Volební systém a strategie hlasování}

$\mathrm{Na}$ chvíli se zastavme u komunálního volebního systému a jeho nastavení v České republice. Charakter a fungování volebního systému v praxi totiž zasahuje jak do institucionálního, tak do behaviorálního typu personalizace, což

${ }^{7}$ Podrobněji viz sekce $2 \mathrm{~b}$ (Volební systém a strategie hlasovánî). 
je pro následující text a zejména operacionalizaci zásadní (srov. Lebeda 2009). Jak již bylo zmíněno výše, účinky komunálního volebního systému v ČR mohou být totiž diametrálně odlišné od toho, co od něj očekávají voliči, když rozdělují hlasy kandidátkám nebo kandidátům.

Volební systém do obecních zastupitelstev je v České republice listinný poměrný. Volič ale disponuje právem panašovat, tedy udělovat preferenční hlasy pomocí křížků. A každý volič má „v ruce“ tolik křížkư, kolik je členů voleného zastupitelského sboru. ${ }^{8}$ Charakteristice volebního systému a jeho pưsobení se věnovala řada textů, na něž jsme poukázali již výše. Celá řada jeho charakteristik ústí do situace, že reálně funguje jinak, než jaký vzbuzuje dojem - ačkoli se skrze možnost preferenčního hlasování a panašování tvárí jako personalizovaný (a zrejmě tak může povzbuzovat fenomén personalizace), fakticky má skryté působení, které jej přibližuje výrazně blíže ke klasickým listinným systémům. To je dáno způsobem, jakým se hlasy přepočítávají na mandáty: Hlas (neboli v našem př́padě křížek) pro osobnost je primárně hlasem pro politický subjekt, na jehož kandidátní listině je daná osobnost v pořadí. Až sekundárně se přihlíží k těmto preferenčním křrižkům, které mohou dané osobnosti pomoci k lepšímu umístění na kandidátní listině a tedy možná i finálně k zisku mandátu. Volič ale může nabýt mylného dojmu a automaticky předpokládat, že když má možnost vybírat kandidáty např́íc listinami, uděluje tím preferenční hlas, tedy volí osobnosti. ${ }^{9}$

Jak souvisí nastavení a charakter volebního systému s personalizací politiky? Cíl zkoumání v rámci této oblasti je zřejmý, nebot' se proměnil vztah elektorátu $\mathrm{k}$ jednotlivým politikům, ve smyslu nárůstu preferencí politických osobností nad jednotlivými stranami. Důležité $z$ tohoto pohledu je i samotné užívání preferenčních hlasů (Voženílková 2014). O tom, že na preferenčním hlasování v komunálních volbách v dlouhodobém měřítku záleží , upozorňují už Balík, Gongala a Gregor (2015: 37) - voliči zkrátka panašování při volbě využívají, a to, jak bylo řečeno výše, pravděpodobně ve víře, že tím vybírají konkrétního kandidáta, a netušíce, že se kř́žek nejprve přičítá kandidujícímu subjektu jako celku. Ve svém důsledku i samotná možnost preferenční hlas využít může mít vliv na voličovo chování a stejně tak i na fenomén personalizace (Balík, Gongala a Gregor 2015: 37). To pak vede částečně i ke změně komunikační a marketingové strategie, k využívání tzv. canddiate-centered strategy - kandidující subjekty pak i ve své předvolební komunikaci sází např. na „zkušené osobnosti“, „úspěšného starostu“, „schopné manažery“, apod. Anebo naopak - jednotliví kandidáti, ve snaze zalíbit se voličům, vedou samostatné individuální kampaně. Oba tyto směry pak ve svém důsledku napomáhají fenoménu personalizace.

\footnotetext{
8 Počet členů zastupitelstva je dán velikostí obce a určujte ho Zákon o obcích a volbách do zastupitelstev obcí č. 491/2001 Sb.

9 Bohužel však doposud nebyl proveden seriózní výzkum, který by hypotézu o neznalosti fungování komunálního volebního systému potvrzoval.
} 
Vedle personalizace jednání politiků probíhá i změna $\mathrm{v}$ chování voličů $\mathrm{v}$ návaznosti na změny $\mathrm{v}$ politickém prostředí a tradičních voličských strukturách. Behaviorální personalizace voličů je založena na hodnocení jednotlivců a identifikaci s nimi, méně na základě stranické identifikace. Strategie hlasování voličů a pravděpodobná neznalost opravdového fungování volebního systému, respektive přepočtu hlasů na mandáty, pak může hrát zásadní roli v personalizaci volebního chování, jak ukáže sekce 3 .

\section{c. Popularita kandidáta}

Proces personalizace je důsledkem interakce několika faktorů. Většina výzkumů logicky tuto komplexní interakci nerespektuje (a ani nemůže respektovat) a soustředí se na jeho jednotlivé části. Ve výzkumu, který se primárně zaměřuje na voliče, lze rozlišovat zkoumání efektu lídra strany (např. Bean a Mughan 1989; Poguntke a Webb 2005; Mughan 2000; McAllister 2007; Karvonen 2010) a obecnějšího efektu kandidátů, kdy je pozornost věnována všem stranickým kandidátům (např. Marsh 2007; van Holsteyn a Andeweg 2010). První prístup je přitom v literatuře dominantní. Obecnější výzkum efektu kandidátů má větší smysl ve volebních systémech, které jsou personalizované (Carey a Shugart 1995). Jak bylo již několikrát zmíněno, ačkoli je volební systém pro volby do obecních zastupitelstev v Česku listinný poměrný, ve voličích velmi často vyvolává právě pocit personalizovaného volebního systému (Lebeda 2009: 332). I proto považujeme za správné tyto charakteristiky zohledňovat i $\mathrm{v}$ př́padě výzkumu personalizace na komunální úrovni.

V souvislosti s personalizací a nastavením volebního systému tak bude důležité operacionalizovat pojem „popularita kandidáta“. Ten v dosavadním výzkumu personalizace není nikterak definován, přesto je pro účely jakéhokoli dalšího výzkumu zásadní. Operacionalizace bude vycházet především z teorie role lídra, inkumbenčního efektu, kumulace mandátů a poměru preferenčních hlasů vưči hlasům pro celou kandidátku.

Proč byly zvoleny právě tyto charakteristiky? Preferenčnímu hlasování jsme se věnovali výše; jde o zásadní a velmi dobře měřitelný ukazatel míry hlasování ve smyslu candidate-centered strategy, o níž jsme hovořili výše. Z hlediska specifika českého komunálního prostředí $\mathrm{k}$ němu volíme kumulaci mandátů, jelikož v České republice není zákonem zakázána, tak jako tomu je např̀. v jiných evropských zemích, a považujeme ji za jeden z určujících faktorů, které mohou $\mathrm{k}$ popularitě kandidáta přspívat. Je to dáno zejména vlivem mediální složky prezentace jednotlivých kandidátů, kteři díky druhému, třetímu či dalšímu mandátu mohou mít více prostoru v médiích a tudíž i obsahu, který budou chtít sdělit a prezentovat svým voličům. (Navarro 2009:11 srov. Hejlík 2016). Samožrejmě existuje i názor, že další mandáty kandidátům mohou škodit (srov. Lebeda 2012), tedy že pokud kandidát chce takř́ikajíc sedět na více židlích, voliče 
to může od udělení křížku odradit. To by se ale mělo dát bez větších obtíží zjistit $\mathrm{v}$ průběhu zpracování dat $\mathrm{v}$ rámci samotného výzkumu a mělo by se to projevit právě na míre popularity daného kandidáta, kterou si tímto definujeme.

Ohledně tzv. inkumbenčního efektu panuje v odborné komunitě poměrně široká shoda v tom smyslu, že se jedná o výhodu (Bernard 2012, Stokes - Miller 1962, Levitt - Wolfram 1997), ${ }^{10}$ a to hned z několika důvodů. Elektorát snáze rozpozná politika, který už úřad aktuálně zastává; kvalita obhájců bývá vyšší než kvalita vyzyvatelů; obhájci jsou pro stranu výhodnější volbou v obvodě; držitelé úřadu vystraší potenciální vyzyvatele (Levitt a Wolfram 1997). Přesto v českém prostř̌edí, byt' v př́ípadě voleb jiného typu (senátních) narážíme na zjištění, že obhajoba mandátu zdaleka není pro kandidáty výhodou (Voženílková a Hejtmánek 2015). To může být dáno, jak Voženílková a Hejtmánek sami připouštějí, odlišností amerického typu volebního systému, z něhož většina zkoumání tohoto efektu vychází. Výsledky na komunální úrovni tak mohou být dalším dílem do skládačky i v případě zkoumání tohoto fenoménu, a také proto jej do návrhu výzkumu zařadíme. Pro výzkum popularity se nabízí i možnost zohledňovat společenskou angažovanost kandidátů - např. fakt jejich členství či funkcionářství ve strukturách občanské společnosti.

\section{Metodologie výzkumu - nástroje a metody}

Přese všechny snahy o sjednocení a utvoření jednotného konceptuálního rámce (Karvoven 2010; srov. Voženíková 2014; Eibl 2016) zůstává personalizace politiky pro většinu politologů poměrně vágním pojmem, který není nikterak ohraničený a je tím pádem i těžko uchopitelný. My se budeme držet tzv. trojdimenzionálního modelu (Kouba 2016: 10), který se skládá z behaviorální, mediální a institucionální personalizace. Pro účely nadesignování dalšího výzkumu bude kruciální právě personalizace behaviorální neboli personalizace volebního chování, částečně pak i personalizace institucionální reprezentovaná právě mechanismem nastavení volebního systému, a personalizace strategie elit ve smyslu sestavování kandidátních listin, ${ }^{11}$ jelikož vztah mezi těmito kategoriemi byl prokázán (viz níže). Ačkoliv, jak již bylo řečeno, všechny tři části by si měly být navzájem rovny a ovlivňovat jedna druhou, behaviorální personalizaci považujeme za tu, kterou by měl výzkum personalizace na komunální úrovni začít. Tato volba je opřena o několik faktorů. Za prvé, výzkum personalizace na komunální úrovni je v české i zahraniční politologii minimální, a pokud se nějaký takový objevil, začínal právě

\footnotetext{
10 Tomu napovídá i jedna z dalších variant pojmenování termínu, a sice výhoda vyzyvatele.

11 Strategii elit ve smyslu volební kampaně, politického marketingu a předvolební komunikace a vlastní sebeprezentace jsme se rozhodli vyhnout z několika důvodů. Tím hlavním a nejdůležitějším je nedostatek relevantních dat. Druhým důvodem je jistá problematičnost analýzy volebních kampaní na komunální úrovni.
} 
soustředěním se na personalizaci volebního chování. Za druhé, volební chování je $\mathrm{v}$ české politologii velmi oblíbeným tématem, které je však značně nepředvídatelné; možnosti výzkumu v této oblasti se zdaleka nevyčerpaly (srov. Balík, Gongala a Gregor 2015; Pink et al. 2013; Šedo et al. 2014). A konečně zatřetí, vzhledem $\mathrm{k}$ nekonečným debatám, které se $\mathrm{v}$ českém prostředí vedou o nastavení volebního systému pro volby do obecních zastupitelstev a debatám na téma volební reformy a zavedení prímé volby starostů, personalizace volebního chování a její výzkum na komunální úrovni může být jedním z hybatelů dalš́ího vývoje $\mathrm{v}$ této oblasti.

Jak by tedy mohla vypadat behaviorální personalizace v rámci české lokální volební arény? Zkusme si ji představit prostřednictvím možnosti a reálného využívání preferenčních hlasů při volbě. Preferenční hlasování si pro tento případ operacionalizujeme jakožto poměr křížků udělených jednotlivým kandidátům oproti kř́žku udělenému politickému subjektu jako celku, respektive kandidátní listině. Identifikovat preferenční hlasování v českých komunálních volbách je však poměrně obtížné a staví nás před rozsáhlou sadu limitů. Tím hlavním je prritom absence detailních volebních výsledků. Ve volbách se totiž zaznamenává pouze celkový počet hlasů obdržených kandidáty a chybí nám tedy přesné rozlišení mezi počty hlasů, které kandidáti obdrželi díky křrižku u svého jména, a počty hlasů, které obdrželi díky kř́žku u kandidátky jako celku. Pakliže chceme a potřebujeme tyto druhy hlasů rozdělit, máme v zásadě tři možnosti Balík, Gongala a Gregor 2015):

1) Lze pracovat s celkovým počtem hlasů odevzdaných pro kandidáta a nerozlišovat, jakým způsobem je získal. Pak je ale nutno počítat s tím, že takto identifikovaný počet hlasů je skutečnému počtu preferenčních hlasů značně vzdálen.

2) Na úrovni jednotlivých kandidátů můžeme pracovat s tzv. prokazatelně preferenčními hlasy, které můžeme odhalit u prvního a druhého kandidáta. Odhad počtu preferencí založený na prokazatelně preferenčních hlasech je pak sice poměrně nízký, nadhodnocuje ale počty hlasů pro kandidáty s vyšším (respektive vzdálenějším) pořadovým číslem. Na druhé straně však př̀i práci s tímto odhadem nedochází ke ztotožnění skutečných preferenčních hlasů s těmi, které kandidát získal jen jakožto součást listiny. Jsme si tím pádem jisti, že jde o skutečné preferenční hlasy pro daného kandidáta.

3) Na úrovni volebního okrsku či skupiny okrsků můžeme stanovit minimální nezbytnou míru využívání preferenčního hlasování, která mohla vést k pozorovanému výsledku. Tento postup sice nedodává smysluplné hodnoty pro jednotlivé kandidáty, může nám však pomoci identifikovat skupiny voličů, kteří ve větší, či naopak menší míře využívají preferenčního hlasování při své volbě. 
Pro účely dalšího výzkumu budeme dále pracovat s variantou č. 2, která nejvíce odhaluje skutečné preferenční hlasy a nezaměňuje je s kř́žzy pro kandidáta $\mathrm{v}$ rámci hlasu pro celou kandidátku. Jiná varianta může být těžko př́ípustná $\mathrm{v}$ př́ípadě, že nám jde o co nejpřesnější zjištění míry popularity kandidáta, která je pŕímo závislá na preferenčních hlasech pro jednotlivé osobnosti v souladu s definicí efektu lídra. Křřžky resp. preferenční hlasy udělované pouze a jen jednotlivým kandidátům totiž plně respektují tvrzení, že lidé volí více na základě svého hodnocení jednotlivců, tedy lídrů, a své vlastní identifikace s nimi. Odpovídají představě, že kvality kandidátů jsou dnes pro voliče důležitějšś než v minulosti, a ctí fakt, že lidé udělování preferenčních hlasů aktivně využívají a zároveň tak reagují na způsob, jakým kandidující subjekty sestavují své kandidátní listiny - jak je obsazují, koho stavějí do čela apod. (srov. Rahat a Sheafer 2007; Balmas et al. 2012).

Vrátíme-li se zpět k rozlišení personalizované volby, objektivně vzato pak lze první variantu (tedy hlasování ve prospěch jednotlivých kandidátů, nikoli kandidátních listin) charakterizovat jako volbu personalizovanou (viz candidatecentered strategy) a druhou jako volbu stranickou (party-centered strategy). Tuto charakteristiku však nepovažujeme za dostačující a přidáváme k ní další indikátor podstatný pro identifikaci míry personalizace volebního chování v českých komunálních volbách. Tento indikátor nazýváme popularita kandidáta. Popularita kandidáta je ukazatel, který udává míru popularity neboli oblíbenosti daného kandidáta ve volebním obvodě, ve kterém kandiduje. Tuto míru popularity určují celkem tři faktory, které považujeme za rovné z hlediska jejich důležitosti (viz výše). První z nich je počet preferenčních hlasů získaných kandidátem, který převyšuje průměrný počet hlasů na kandidáta na dané kandidátní listině. Druhým je fakt znovuzvolení, tedy objektivní fakt, že se kandidát uchází o funkci v zastupitelstvu, kterou získal už v předchozím volebním období. Třetí charakteristikou je kumulace mandátů, tedy jinými slovy objektivní fakt, že kandidát $\mathrm{v}$ době své kandidatury disponuje mandátem $\mathrm{z}$ jiné úrovně voleb - tedy je zároveň senátorem, poslancem, europoslancem, či krajským zastupitelem, radním nebo hejtmanem.

K jednotlivým faktorům mohou být přiřazeny nominální hodnoty, a to následovně:

1. Preferenční hlasy pro kandidáta vs. průměr preferenčních hlasů na kandidátce

a) Kandidát ziskal méně preferenčnich blasì, než je priomèrný počet blasư na kandidáta v rámci jeho kandidátky $=0$

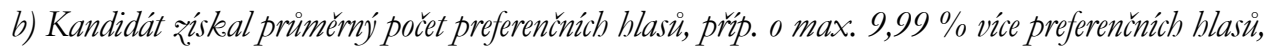
než je primmèrný poúet hlasu na kandidáta v rámci jeho kandidátky $=1$

c) Kandidát získal o 10 a více \% preferenčnich blasư, nežje prümèrný poùet blasu na kandidáta $v$ rámci jebo kandidátky $=2$ 
Hranice mezi 9 a $10 \%$ je nastavena podle toho, jak je nastaven volební systém do obecních zastupitelstev - v něm je $10 \%$ hranice je určující pro změnu pořadí kandidátů na kandidátce, tzv. přeskakování.

\section{Inkumbenční efekt neboli znovuzvolení}

a) Kandidát byl znovuzvolen $=2$

b) Kandidát nebyl znovuzvolen $=0$

c) Kandidát v predchozích volbách nekandidoval = 1

$\mathrm{V}$ této kategorii je potřeba zohlednit objektivní fakt, a sice že narazíme na kandidáty, kteří mandát ve volbách 2014 neobhajují. Oblíbení nebo populární ale mohou být i $\mathrm{z}$ jiného důvodu (např. díky povedené prezentaci a komunikaci v rámci volební kampaně), proto je nebudeme penalizovat např́klad odečtem bodu.

\section{Kumulace mandátů}

a) Kandidát nedisponuje žádným jiným mandátem $=0$

b) Kandidát disponuje jedním dalš́m mandátem $=1$

c) Kandidát disponuje dvèma a více dalšimi mandáty $=2$

Zde vycházíme z předpokladu, že čím více mandáty kandidát disponuje, tím více je pro veřejnost známější a oblíbenější. Dostává se mu více prostoru v médiích pro vlastní prezentaci a komunikaci směrem $\mathrm{k}$ voličům, což obvykle bývá ve volební kampani výhodou.

Př́kladem testování popularity kandidáta tak může být kandidát Josef Novák, kandidující do obecního zastupitelstva v obci Horní Lhota (viz Tabulka č. 1). Josef Novák obhajuje starostenský post a $\mathrm{v}$ průběhu výkonu svého mandátu byl v roce 2012 zvolen i do horní komory parlamentu. Starostenský mandát se mu podařilo obhájit. Kandidoval z první pozice a počet jeho preferenčních hlasů byl vyšší než $110 \%$ průměru hlasů jeho kandidátní listiny. Míru jeho popularity jako kandidáta proto hodnotíme číslem 5 , tedy jako vysokou míru popularity.

Míru personalizace na komunální úrovni v ČR pak bude představovat vyhodnocení dvou výše zmíněných indikátorů dohromady. Tedy sečtení čísla určujícího průměrnou míru popularity kandidáta a hodnoty udávající poměr mezi křrižky udělenými kandidátovi a kř́žzy udělenými kandidátní listině jako celku. Podobně jako $\mathrm{v}$ prŕpadě indikátoru popularita kandidáta budeme zjišt'ovat míru personalizace $\mathrm{v}$ dané obci (volebním obvodě) na škále nulová, nį́ká, strédní, yysoká. Abychom byli schopni říct, jaká je průměrná míra personalizace v ČR, použijeme běžný aritmetický průměr ze všech zkoumaných volebních obvodů. 


\section{Tabulka č. 1: Operacionalizace termínu popularita kandidáta}

\begin{tabular}{|l|c|}
\hline & $\begin{array}{c}\text { Preferenční hlasy vs. hlasy pro kandidátku } \\
+ \text { inkumbenční efekt + kumulace mandátů }\end{array}$ \\
\hline Nulová míra popularity & 0 \\
\hline Nízká míra popularity & $1-2$ \\
\hline Střední míra popularity & $3-4$ \\
\hline Vysoká míra popularity & $5-6$ \\
\hline
\end{tabular}

Zdroj: autoři

Takto designovaný výzkum by se zabýval i tím, zdali (popř́padě jak moc) se voliči řídí při rozhodování individualitou kandidátů. ${ }^{12}$ Zjiššovat pak můžeme i další detaily, např́klad to, jak moc odráží personální složení nově zvoleného zastupitelstva sociodemografický profil dané obce či města, zdali existuje strategie pro sestavování kandidátních listin a obsazování jednotlivých pozic na kandidátce podle určitého klíče a podobně.

K zodpovězení výzkumných otázek či k prípadnému k testování hypotézy by měly sloužit dva typy dat. Výzkum by měl primárně vycházet $z$ volebních výsledků komunálních voleb. K nim je nutné získat i volební výsledky z bezprostředně předcházejících voleb do krajských zastupitelstev, do poslanecké sněmovny 2013 a třech bezprostředně předcházejících voleb do Senátu. Potřebná budou také sociodemografická data ze sčitání lidu bud' těsně předcházejícího komunálním volbám, nebo těsně následujícího.

Druhým podstatným zdrojem dat by mělo být vlastní dotazníkové šetření, jehož výsledky by měly doplnit výstupy získané z analýzy volebních výsledků a prrípadně charakter personalizace na komunální úrovni. Zajímavým zjištěním mohou být např́klad osobnostní charakteristiky, se kterými se voliči u kandidátů ztotožňují, jakou roli hraje inkumbenční efekt, kumulace mandátů a konečně také to, do jaké míry voliči rozumí komunálnímu volebnímu systému.

Výběr vzorku obcí by měl být náhodný dvouúrovňový, př́padně populační kvótní výběr. Měl by reprezentovat populaci ČR v jednotlivých krajích a zároveň odpovídat velikostním kategoriím českých, moravských a slezských obcí.

12 Podstatné je slovo „kandidátư“ nikoli „lídrů (srov. efekt lídra). Považujeme totiž za důležité zabývat se i efektem dalších kandidátů, kteří jsou na dané kandidátce až za lídrem. Jejich oblíbenost totiž může mít vliv na výsledek celé kandidátní listiny. To už jsme ale zpět u termínu „popularita kandidáta“. 
Referenčním rámcem pro určení velikostních kategorií obcí bylo zvoleno Outlého (2004: 16) schéma, jež rozděluje obce do kategorií do 100 obyvatel, 101-300 obyvatel, 301-500 obyvatel, 501-1 000 obyvatel, 1 001-3 000 obyvatel, 3 001-5 000 obyvatel, 5 001-10 000 obyvatel a nad 10000 obyvatel, přičemž posledně zmíněná kategorie byla rozdělena na dvě, 10 001-50 000 obyvatel a nad 50001 obyvatel, čímž bylo (téměř) zohledněno rozlišení mezi městy a statutárními městy. Všech devět určených velikostních kategorií obcí ve zkoumaném období vykazuje poměrně stabilní četnost.

Výše zmíněné jevy budou zkoumané a hodnocené s ohledem na rozdělení obcí dle velikosti, abychom byli schopni reflektovat potenciální varianci s ohledem právě na velikost obce. Vedlejší výzkumné otázky budou zodpovězeny na základě porovnání dat, která získáme z analýzy volebních výsledků (př́padně socio-demografického profilu) a $z$ dotazníkového šetření. Dotazníkové šetření by mělo přinést unikátní data podstatná pro celkovou analýzu, tak, jak je nastíněna výše.

Kalkulujeme s předpokladem, že jistá míra personalizace se na komunální úrovni v Česku objeví. Měli bychom být schopni konstatovat, že tento fenomén na komunální úrovni vČR ve volbách v roce 2014 existuje, což v zásadě znamená, že volební systém, který ze své podstaty reflektuje strategii orientovanou na kandidátní listiny a nikoli personální hlasování, není ovlivněn personalizací volebního chování. To samé pak platí i v opačném směru, jelikož debaty o změnách $\mathrm{v}$ rámci volebního systému nebo o celé volební reformě se sice vedou, ale prozatím $\mathrm{k}$ ní nebylo $\mathrm{v}$ praxi přistoupeno.

\section{Závěrem}

Předkládaný text si kladl za cíl představit konceptuální rámec fenoménu personalizace na komunální úrovni v České republice a možnosti jeho dalšího zkoumání prostřednictvím originálního návrhu designu empirického výzkumu. Personalizace je totiž dynamicky se rozvíjejícím fenoménem, který prolíná politiku na úrovni národní, ale pravděpodobně i regionální a lokální. Komunální volby $\mathrm{v}$ České republice byly předmětem právě tohoto textu, a to $z$ několika důvodů. Předně se v otázce personalizace jedná o oblast v politologii zatím neprobádanou české i zahraniční texty se intenzivně věnují personalizaci celostátní politiky, ale lokální aspekty jsou stále opomíjeny. A co je důležitější - fenomén personalizace může hrát velmi podstatnou úlohu v potenciální volební reformě. Zatím totiž ještě neproběhl komplexní výzkum voličského chování na komunální úrovni, který by dokázal popsat či vysvětlit strategii rozhodování voličů prí komunálních volbách. Neexistuje ani takový výzkum, který by dokazoval, že volební systém pro volby do obecních zastupitelstev v České republice je skutečně pro voliče tak matoucí a nesrozumitelný, jak se politologové domnívají. Předkládaný text tedy nabízí výzkumný design, který může být jednou z možností, jak k výzkumu personalizace 
na komunální úrovni přistoupit a jak potvrdit či vyvrátit výše zmíněné hypotézy. Jedná se o design kvantitativního charakteru, díky kterému bude možné zjistit, zda personalizace na komunální úrovni v ČR vůbec existuje, a dále nabízí indikátory, jejichž prostřednictvím může být personalizace na úrovni lokální volební arény měřitelná. $\mathrm{Na}$ jedné straně pracuje s indikátory, které jsou (nejen) české politologické obci velmi dobře známy, jako je preferenční hlasování, incumbency effect a další, ale zároveň príchází se zcela novými. Mezi takové patří popularita kandidáta, která byla $\mathrm{v}$ rámci předkládaného textu představena. Takto designovaný výzkum může v neposlední řadě přispět ke komplexnějšímu pojetí fenoménu personalizace a může také poodhalit souvislosti mezi jejími jednotlivými úrovněmi, prúćcinami a důsledky ve specifickém komunálním prostř̌edí v České republice.

\section{Bibliografie}

Poznámka: elektronické zdroje ověreny k 25. 12. 2018

Balík, S., Gongala. P. a Gregor, K. (2015). Dvacet let komunálnich voleb v ČR. Brno: CDK. Balík, S. (2009). Komunální politika: obce, aktéri a cíle mistní politiky. Praha: Grada Publishing. Balík, S. (2016). „Local Cleavages, Politics and Policy at the Local Level - Is the Depolitization Real?“. Sociální studia 13(1): 73-85.

Bernard, J. (2012). „Individuální charakteristiky kandidátů ve volbách do zastupitelstev obcí a jejich vliv na volební výsledky." Sociologický ćasopis 48(4): 630-640.

Biler, S. (2008). Sociálni a politické konsekvence procesu individualizace [rukopis]. Diplomová práce, Masarykova univerzita, Fakulta sociálních studií

Blamas, M. et al. (2012). „Two routes to personalized politics: Centralized and decentralized personalization." Party Politics 20(1): 37-51. DOI /10.1177/1354068811436037

Bittner, A. (2011). Platform or personality? The role of party leaders in elections. New York: Oxford University Press.

Caprara, G. V. a Zimbardo, P. G. (2004). „Personalizing Politics: A Congruency Model of Political Preference.“ American Psychologist 59(7): 581-594. DOI 10.1037/0003-066X.59.7.581

Carey, J. M. a Shugart, M. S. (1995). „Incentives to Cultivate a Personal Vote: a Rank Ordering of Electoral Formulas." Electoral Studies 14 (4): 417-439. DOI 10.1016/02613794(94)00035-2

Čaloud, D. (2006). „,Volební systém a volební inženýrství: současný stav a možné změny“. In: Čaloud, D. Foltýn, T., Havlík, V. a Matušková, A. (eds.) Volby do Poslanecké snémovny v roce 2006. Brno: CDK, 145-163.

Čmejrek, J. (2005). „Specifika komunální politiky v malých obcích ČR.“ In: Dančák, B., Fiala, P. a Hloušek, V. (eds.), Evropeizace: nové téma politologického výzkumu. Brno: IIPS, 72-87

Dalton, Russel J. (2002). Citizen Politics: Public opinion and Political Parties in advanced Western democracies. New York: Catham House Publishers.

Eder, N, Jenny, M. a Muller, W. (2015). „Winning over voters or fighting party comrades? Personalized constituency campaigning in Austria." Electoral Studies 39(3): 316-328. DOI 10.1016/j.electstud.2014.04.008 
Eibl. O. (2016). „Cesta k (experimentálnímu) výzkumu efektů osobnostní stránky politiky pod jednou konceptuální střechou: metodologická poznámka k výzkumu personalizace. European Electoral Studies 11(1): 34-43.

Garzia, D. (2011). „The personalization of politics in Western democracies: Causes and consequences on leader-follower relationships." The Leadership Quarterly 22(4): 697-709. DOI 10.1016/j.leaqua.2011.05.010

Chytilek, R. et al. (2009). Volebni systémy. Praha: Portál.

Karvonen, L. (2010). The personalization of politics: Study of parliamentary democracies. Colchester: ECPR Press.

Kouba, K. (2016). Personalizace voleb a demokracie v Latinské Americe. Brno: CDK.

Kriesi, H. (1998). „The transformation of cleavage politics: The 1997 Stein Rokkan lecture.“ European Journal of Political Research, 33(2): 165-185. DOI 10.1111/1475-6765.00379

Lebeda, T. (2001a). „Hlavní proměnné proporčních volebních systémů“. Sociologický casopis 37(1): 425-447.

Lebeda, T. (2001b). „Přirozený práh poměrných systémů, teorie a realita“. Politologický casopis 8(2): 134-149.

Lebeda, T. (2009). „Komunální volby klamou. Krátké zastavení nad problematickými aspekty volebního systému pro obecní zastupitelstva.“ Acta Politologica 3(1): 332-343.

Lijphart, A. 1994. Electoral Systems and Party Systems: A Study of Twenty-Seven Democracies, 1945-1990. New York: Oxford University Press.

Linek, L. a Voženílková, M. (2017). „Strany na ústupu, lídři na vzestupu? Personalizace volebního chování v České republice.“ Sociologický časopis 50(2): 147-180. DOI 10.13060/00380288.2017.53.2.304

Lipset, M. S. a Rokkan, S. (1967). Party Systems and Voter Alignments: Cross-National Perspectives. New York: Free Press

McAllister, I. (2007). „The Personalization of Politics.“ In: Dalton, R., Klingemann, H.-D. (eds.), Oxford Handbook of Political Behavior. Oxford: Oxford University Press, 571588. DOI 10.1093/oxfordhb/9780199270125.003.0030

Outlý, J. (2004): „Volby do zastupitelstev v obcích - vývoj a souvislosti.“ In: Šaradín, P. a Outlý, J. (eds.), Studie o volbách do zastupitelstev v obcích. Olomouc: Univerzita Palackého, 11-45.

Pecháček, Š. (2013). „Personalizace politiky v ČR.“ Revue politika 19(2): 93-109.

Pink, M. et al. (2013). Volebni mapy Ceské a slovenské republiky po roce 1993: vzorce, trendy, promèny. Brno: CDK.

Šedo, J. et al. (2014). Ceské prezidentské volby v roce 2013. Brno: CDK.

Šůstková, M. (2007). "Silvio Berlusconi a Forza Italia: fyziognomie marketing lídra." In: Šaradín, P. (ed.), Politické kampaně, volby a politický marketing. Olomouc: Periplum, 53-68

Taagepera, R. a Shugart, M. (1989). Seats and Votes: The Effects and Determinants of Electoral Systems. New Haven: Yale University Press.

Van Zoonen, L. (2005). Entertaining the Citizen. Lanham: Rowman\&Littlefeld

Voženílková, M. (2014). „Co je a co není personalizace politiky?“ Global Politics, on-line (http://www.globalpolitics.cz/clanky/co-je-a-co-neni-personalizace-politiky)

Voženílková, M. a Hejtmánek, J. (2015). „Koncept Incumbency Advantage v českých senátních volbách." Stredoevropské politické studie 17(1): 1-27. DOI 10.5817/CEPSR.2015.1.1 